Joanna Dembińska-Pawelec

\title{
Arachne z ulotną nicią. Sygnatura kobieca w późnej poezji Bogusławy Latawiec
}

Poezję Bogusławy Latawiec w jej najbardziej źródłowym wymiarze przenika dążenie poznawcze, które ukierunkowane jest ontologicznie. Autorka próbuje rozpoznać tajemnice - jak mówi - „ludzko-zwierzęco-roślinnego" istnienia [R: 78], przenika i oświetla metafizyczne przestrzenie bytu, odkrywa oraz penetruje własne, wewnętrzne głębie, jednocześnie w szczególny i poetycki sposób zacierając granice dzielące wszystkie te obszary. Zastanawia się także nad naturą czasu aktualnego, a zarazem przenikającego się z przeszłością, nigdy niedostępną, ale uobecniającą się momentalnie we wspomnieniu czy reminiscencji. Podejmuje temat sztuki, ekfrastycznego przetworzenia dzieła w poetyckim, jednostkowym spojrzeniu. Zagadnienia, obserwacje, rozpoznania ukazują się w jej wierszach zaledwie migotliwie, fragmentarycznie, $w$ ułamkowym błysku świadomości jako ślad, przeczucie, domysł, nagłe widzenie. Perspektywa poznawcza sprawia, że jej twórczość postrzegana jest jako intelektualna, trudna, wymagająca. Taki zresztą odbiór projektuje sama poetka - w posłowiu zatytułowanym Głośne jest to, co najcichsze do tomu Razem tu koncertujemy zaznacza, że czytanie wierszy „wymaga od czytelnika, by przyjąl punkt widzenia poety, 
jego prawa porządkujące świat imaginacji, sensu i znaku, żąda przy lekturze odwagi”, a wszystko to, by „przechwycić i oswoić świat autora" [R: 77].

Mistrzami i nauczycielami sztuki poetyckiej, których wpływ na własną twórczość poświadcza Latawiec, są Bolesław Leśmian, Tymoteusz Karpowicz, Julian Przyboś, Paul Valéry oraz Gennadij Ajgi. To panteon wyłącznie męski, w dodatku przynależą do niego przedstawiciele ruchu nowoczesnego i awangardowego. Być może ten właśnie męski patronat wraz z intelektualną postawą poetki sprawiły, że już jej debiutancki tom Otwierają się rzeki (1965) opatrzono etykietą: „poezja niezbyt kobieca” [Fornalczyk 1965]. Trzydzieści lat później Wiktor Woroszylski wciąż powtarzał i utwierdzał tę opinię, pisząc następująco:

Bogusława Latawiec, która w ciągu bez mała trzydziestu lat wydała pięć tomów wierszy [...] należy do znaczącej we współczesnej literaturze polskiej plejady poetek, twórczość jej nie mieści się jednak (jak zresztą i twórczość niektórych innych spośród tejże plejady) w kategoriach „poezji kobiecej”. Jeżeli w ogóle potrzebne jest jakieś przyporządkowanie, to autorkę „nigdy całości” należałoby umieścić w wybitnie „męskim” nurcie „awangardowym” i „lingwistycznym”, wiązanym z nazwiskami Przybosia i Karpowicza. [Woroszylski 1995: 9]

Co prawda dostrzega Woroszylski, że poetka „nie przejęła oschłości mistrzów, «ociepliła», userdeczniła obrany wzorzec, przedkładając w sumie odmienny i nader interesujący wariant «nowoczesnej» liryki" [Woroszylski 1995: 9] ${ }^{1}$, nie zmienia to jednak jego generalizującej klasyfikacji. Taka uzurpacja męskiego osądu nie należy w krytyce literackiej do zjawisk wyjątkowych. Przypomnę „W takiej właśnie świetlistej wizji ludzkiej egzystencji zbliża się poezja Latawiec do poszukiwań liryki Przybosia [...], tutaj jest jej najbliższa, lecz zarazem i przekracza jej horyzont poprzez nałożenie na siebie, przemieszanie doświadczenia jawy i snu, poprzez więc wychylenie w te obszary, jakie otwiera poetyka surrealistyczna” [Szaruga 2000: 137]. 
tylko, że Michał Głowiński o naszej noblistce pisał: „Wisława Szymborska jest wielkim poetą. Takim, którego można postawić obok najwybitniejszych poetów polskich II połowy $\mathrm{xx}$ wieku: Czesława Miłosza, Zbigniewa Bieńkowskiego, Tadeusza Różewicza, Mirona Białoszewskiego" [Głowiński 1996: 46].

Lirykę Latawiec odczytuję inaczej niż Woroszylski. W moim odczuciu jej twórczość jest właśnie bardzo kobieca, prezentująca sfeminizowany sposób odczuwania, wyrażania, wrażliwości oraz sfery imaginacji. Autorka korzysta z wypracowanych technik poetyki awangardowej i chwytów lingwistycznych, ale czyni to na sposób wyraźnie kobiecy. W dalszej części szkicu postaram się to przybliżyć.

$\mathrm{Na}$ opozycyjną grę elementów męskich i żeńskich obecną w wierszach Latawiec zwracała uwagę Anna Węgrzyniakowa w szkicu Uczennice Przybosia. Wskazywała ona na „fundamentalne dla tej liryki napięcie pomiędzy «jasnym», męskim gestem kreacji $[\ldots]$ a «ciemnym», kobiecym żywiołem istnienia psychosomatycznego" [Węgrzyniakowa 2002: 184]. Konsekwencją tego, przekonuje badaczka, jest odmienny sposób postrzegania świata:

W poetyckim świecie Latawiec „,męskich”, agresywnie projektujących spojrzeń nie znajduję. Jej „kobiecy” podmiot widzi więcej, gdy przymknie oczy i dla takiego widzenia „wewnętrznego” [...] poetka próbuje znaleźć „obrazowy” język metafor. [Węgrzyniakowa 2002: 186]

Kobiecą odmienność autorki Razem tu koncertujemy ukazywała Joanna Grądziel-Wójcik. Z jednej strony zwróciła ona uwagę na intelektualizm podmiotowego poznania zapisany $\mathrm{w}$ wierszach Latawiec, z drugiej - na sensualną wrażliwość: spojrzenie dotykające, wnikanie w materię, zaglądanie do wnętrza ciała. Zestawiając tę lirykę z utworami Przybosia, Grądziel-Wójcik pisała: „Latawiec idzie zatem dalej niż Przyboś w swych poetyckich poszukiwaniach, odkrywając w świecie i w sobie «ciemnię», w której gromadzą się wszelkie lęki i przeczucia” [Grądziel-Wójcik 2016b: 158].

W niniejszym szkicu chciałabym przede wszystkim przyjrzeć się sferze kobiecej, a raczej sygnaturze kobiecej, wpisanej w wier- 
sze Latawiec, jest ona bowiem rodzajem jej autorskiego podpisu. Odwołam się przy tym do znanej propozycji Nancy K. Miller i jej teorii tekstu jako arachnologii. Badaczka analizowała tropy feministycznej aktywności literackiej i posługiwała się przy tym przykładem kobiecego tkactwa uosobionego w micie o Arachne. Objaśniając praktykę lektury topograficznej, pisała:

Chcemy przypomnieć, że Arachne, artystka pajęczyca, zaczyna jako tkaczka tekstów. Przez arachnologię zatem rozumiem ustawienie krytyczne, pozwalające czytać na przekór niezróżnicowanemu utkaniu, aby odkryć wcieloną w pisanie określoną genderowo podmiotowość; aby odzyskać w obrębie przedstawienia emblematy jego konstruowania. [Miller 2006: 492]

Zadanie arachnologii, które chciałabym podjąć w odniesieniu do poezji Latawiec, Miller zdefiniowała jako: „szukanie w lekturze Arachne, to znaczy nie tylko jej, «innej kobiety», ale szukanie w lekturze gdzie indziej i na inne sposoby emblematów jakiejś żeńskiej sygnatury" [Miller 2006: 511].

W twórczości Latawiec znajdziemy bowiem sporo owych emblematów. W najnowszym tomie Zmowy pojawia się nawet sama postać Arachne w wierszu zatytułowanym Arachne gubi sandat. Utwór, opatrzony datą „październik 2011 r.”, jest zapisem reakcji na zajścia w Atenach - wystąpienia młodzieży, demonstracje ludności i starcia z policją. Arachne jako jedna z uczestniczek protestów, która - również jako kobieta - bezpośrednio doświadczała wydarzającej się historii, może swoim zwyczajem artystki-pajęczycy utkać tekst i wpisać te zdarzenia w opowieść o opresji:

W Atenach szyby tłuką pięści

kamienie rodzą krew

Arachne gubi sandał uciekając brukiem przez żywą pajęczynę szkła.

[Z: 12] 
Metafora „żywa pajęczyna szkła” odsyła do mitologicznej opowieści, a także teorii tekstu jako tkania pajęczej nici, jednak przede wszystkim osadza nas wyraźnie i niemal sensualnie we współczesności, ujawniając jej brutalne oraz krwawe oblicze.

Wiersz Arachne gubi sandat pozostaje autorskim znakiem, potwierdzeniem świadczącym o istotności sygnatury arachnologicznej w liryce Latawiec. Najczęściej jednak odwołanie do mitu o Arachne pojawia się w twórczości autorki Razem tu koncertujemy w wierszach o charakterze metatekstowym, w których za pomocą kobiecej pracy tkania ukazana zostaje czynność tworzenia. Jest ona, jak ukazuje poetka w wielu swoich utworach, zawsze uwikłana w czas, stąd motyw szycia i tkania często łączy się z problematyką temporalną, jak w wierszu zatytułowanym Okno:

A czas jest z nici szczelnie zamotany

Płócienna pamięć

Biegnę przez nią wstecz i z powrotem

ja i one wszystkie te

którymi byłam

Cała nas gromada

Godzinami więc patrzę sobie samej

Prosto w oczy.

[R: 23]

Pamięć ukazana jest tutaj w postaci płótna, na którym poetka, jak Arachne, za pomocą nici czasu tka swoje doświadczenia, utrwala historie, przeżycia, stany minione. Płócienny obraz pamięci niczym tkanina mitologicznej prządki zachowuje i odwzorowuje życie w jego przebiegu. Spoglądając na wyszyte tam sceny, można godzinami kontemplować oraz rozpamiętywać przeszłość, przyglądać się samej sobie, patrzeć „prosto w oczy”, otwarcie i intymnie, bez przesłony ${ }^{2}$. Podobnie zapisuje autorka w wierszu Dzierlatka (2):

2 Adriana Szymańska, omawiając wiersze Latawiec z tomu Razem tu koncertujemy, następująco pisała na temat koncepcji czasu: „W wierszach B. Latawiec wszystko dzieje się w czasie pomieszanym, czasie którego nie ma, gdzie teraz graniczy z przeszłością, imaginacja odmienia rzeczywiste, a wspomnienia i marzenia otrzymują konkretny byt" [Szymańska 1999: 368]. 
W ciasnocie snu, pamięci

nadal jesteśmy razem

choć ona to już nie ja

ja nie ona

Nocą pod płótnem śniegu

[...]

pilnuję jej kroków

jak nici

szczelnie motanej wokół

kłębka czasu.

[G:21]

Nić życia motająca się na kłębek czasu nocą „pod płótnem śniegu” przesuwa się w pamięci, haftuje obrazy wspomnień, przypomina dawną siebie i przywraca na moment minione chwile. Można domyślać się, że przechowywane „w ciasnocie snu, pamięci” obrazy są drogie sercu, bo „ja” w wierszu mówi: „pilnuję jej kroków”, jakby bała się ją - a zarazem samą siebie dawną - utracić. Wojciech Ligęza pisząc o utworach Latawiec, zauważał: „Życie refleksyjne to odczytywanie i zarazem zapisywanie własnego losu. Poezja okazuje się niezbędna, ustanawia bowiem sankcję i sens istnienia" [Ligęza 1983: 121].

Poetka-Arachne tka oraz zapisuje nie tylko siebie, potrafi także wpisać tego, z którym łączą ją więzy najmocniejsze, najbardziej ścisłe i intymne. Za pomocą nici czasu przechowany pozostaje ktoś najbliższy, najdroższy, wart nieustannej uwagi, jak w wierszu Klatki:

\section{Zaplątana w minione}

niczym w owczą wełnę

[...]

Krążąc wśród liter twojego imienia

[...]

przepisałam twoją twarz

okrągłym pismem

$\mathrm{z}$ życia w sen.

[G:39-40] 
Tkanie, podobnie jak w przypadku Arachne, staje się tu formą zapisu, utrwalania obrazu, wyszywania portretu, mimetycznego przepisania „z życia w sen”, w sferę wewnętrzną, w której rodzi się sztuka. Owcza wełna odnosi nas również do innej mitologicznej kobiety, Medei, wiernej kochanki oraz żony gotowej dla miłości wyjawić rodzinne tajemnice, a także Penelopy nieustająco i bez końca tkającej całun.

Arachnologiczna metafora haftu oraz tkania znajduje też interesujące egzemplifikacje $w$ wierszach ekfrastycznych autorki Odkrytek. Albowiem Latawiec, jak zauważył Piotr Łuszczykiewicz, „pokazuje, jak czyta obraz poeta, przebijając się przez kolejne warstwy olejne farby aż do samego blejtramu, aż do malarskich krosien" [Łuszczykiewicz 2016: 26]. To właśnie płótno obrazu niczym utkany materiał Arachne - jest tym, do czego próbuje w swoim poetyckim spojrzeniu dotrzeć Latawiec. W utworze Ostatni Rembrandt zapisuje ona:

Kroplą czerni zapętlonej w pędzlu jak węzełek na końcu nitki dotknąłeś lewej źrenicy tego starca z płótna. [Z: 44]

Podobnie podkreśla w wierszu Strusie jajo Piera della Franceski:

Odwaga z którą wchodzimy w obrazy<smiles>[CH]1[CH]NC1</smiles>

te co milczą aż podwójnie: $w$ nas i na swoich deskach, płótnach $[\ldots]$.

[O: 43]

W utworze Ilu nas porwanych $\mathrm{z}$ umieszczonym w nawiasie mottem „Według Boscha” wprost powiada: 
dna tam nie ma

tylko napięte pod blejtramem

płótna.

[O: 45]

Poetka niczym Arachne wplata swoje przeżycie w płótna blejtramów, wszywa nitkę tekstu w krosna arcydzieł ${ }^{3}$.

Motyw nici - tkających, haftujących, powiewających - przewija się często w twórczości Latawiec. Oto kilka przykładów:

Dwa głosy w jednej nici szeleszczącej ponad planetą;

[R: 72]

spleciony z białej bawełny [... $]$

jak cień nici wyrwanej

z kłębka

polatywał jedynie $\mathrm{z}$ wiatrem;

[Z: 21]

taka cisza jakby motek

gonił motek wełny;

[Z: 62]

„Z nitkami gniewu w oczach” [Z: 40]; „Ich biel to jedynie mgielna nić” [Z: 38]; „węzełek na końcu nitki” [Z: 44]; „biała nić śmiechu” [R: 58]; „Zsunął ci na dłoń złotą nić olejną” [O: 46]. Do tego pola semantycznego dołączyłabym także wyrażenia, w których ukazany jest puch i pierzastość, tak często zresztą obecne w wierszach Latawiec. Pojawiają się one w podobnym kontekście jak kłąb wełny czy splot nici, na przykład: „Z gniezdnego puchu” [Z: 35]; „pierzaste cichostany” [Z: 23]; „puch mleczy” [Z: 22$]$; „jak puchy nasion”

3 Anna Mazurek pisząc o wierszach-ekfrazach Latawiec, zauważyła: „Kontakt $\mathrm{z}$ arcydziełami stanowi zatem ważne doświadczenie egzystencjalne, gdyż pozwala człowiekowi spleść różnorodne pasma czasu i osiągnąć stan pełnej obecności, maksymalnej intensywności istnienia" [Mazurek 2008: 138]. 
[G: 14]; „Świergotów myśli i treli pierzastych” [G: 36]; „ściana pierzastej bieli” [Z: 36]; „puch i biel bez ciężaru” [G: 37]; „puch porwany” [O: 14]; „puchy na nasze dłonie splecione" [O: 44]; „Oświetlił głowy puchem” [O: 52]. Towarzyszą im czasowniki oznaczające splatanie, zwijanie, supłanie, wiązanie, ale też ich przeciwności - rozsuplywanie czy rozwiazywanie. Znajdziemy również $\mathrm{w}$ lirykach metaforyczne słowa i wyrażenia związane z czynnościami haftowania oraz szycia: „oko igły” [O: 46]; ,igłę zanurzam” [R: 8]; „z nałożenia jednego szwu na drugi” [G: 28].

Najczęściej, jak wspomniałam, motyw nici, wełny, puchu i tkania wiąże ze sobą sferę czasu, pamięci oraz tworzenia. Tak również jest w wierszu Pod stopą:

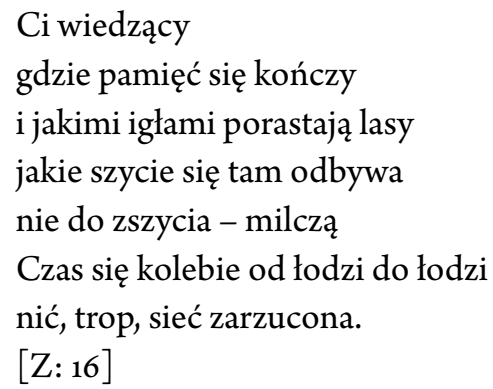

Rzeczywistość będąca domeną „wiedzących”, w której odbywa się „szycie” zdarzeń „nie do zszycia”, pozostaje niewypowiedziana, zalega w milczeniu. Jedynie poetycka pamięć, „kolebiąca czas”, zatrzymuje je w przeczuciu. Nić pamięci jako trop rzeczywistości splata się $\mathrm{w}$ sieć tekstu tkaną przez poetkę $\mathrm{w}$ doświadczaniu oraz słuchaniu znaków świata. Te zaś przekształcają się, jak we wzorzystej tkaninie, w wizualne, ale i synestezyjne obrazy. Piotr Michałowski zauważał, że synestezje w utworach Latawiec nie powstają „ze składników równoważnych, ale zwykle wzrok staje się interpretatorem słuchu" [Michałowski 1999: 81]. Tak jest w wierszu Epifania:

Tutaj szelest każdy nauczyłam się widzieć Błysk nici słyszę o zmierzchu gdy igłę zanurzam w guziku 
białą pętlę zwiniętą jak nadsłuchujące

ucho

Czyje to sprzed lat słuchanie

czyich palców

[...]

czas cofnął się za czas

za nitkę zwiniętą jak ucho

nasłuchujące.

[R: 8]

Epifania w swej warstwie metatekstowej zdradza nam sekret tworzenia. Proces poetycki - tkanie tekstu - zestawiony jest z czynnością szycia, dziergania, plecenia pętelki z nici. W poetyckiej kontaminacji nakładają się obie te sfery jako aktualne doznanie, skupienie wewnętrzne, nasłuchiwanie minionego i nagłego zdarzenia, które odwraca jak „turlająca się” szpulka normalny bieg zdarzeń, bo „czas cofnął się za czas / za nitkę zwiniętą jak ucho / nasłuchujące”. W szczelinie nici czasu, zaplecionej pętelce, może objawić się epifanijne uchwycenie odmienności bytu.

Motywom nici, tkania, szycia, splatania towarzyszą obrazy, metafory czy porównania, w których pojawiają się materiały, sukna oraz prześcieradła. Spójrzmy na przykłady:

Gdyby tak biel policzyć wzdętych nad ulicami prześcieradeł koszul, serwet i fartuchów;

$[\mathrm{G}: 5]$

Nocą słyszę powietrzne

Polany tlenu, prześcieradła

słodyczy, jedwabne płuca;

[R: 7]

szeleszczą

całe w serwetach, prześcieradłach;

[R: 16] 
codziennie płuczę dłonie

w chłodnej rzece czasu

to chusty z odbiciem twojej twarzy;

[R: 50$]$

Wiatr obraca chmurą jak belą jedwabiu

Rozwija ją i zwija;

[R: 57]

leży na łące równo złożony

niczym stos białych prześcieradeł;

$[\mathrm{Z}: 27]$

Gdy dotykał płócien

swoimi

oczami;

[Z: 45]

biel ulotna

z płóciennych powłok za oknami;

[G: 5]

„Za plecami płuczą się jasne chusty ziemi” [R: 46]; „pod palcami jak szorstkie płótna” [Z: 13]; „prześcieradła bieli” [Z: 45], „jakby była chustą morza” [G: 54]; „słyszę jedynie ciszę w ciszę owiniętą" [Z: 27]; „wstążkę z białej tafty w róże wezmę z sobą” [O: 15]; „przedarłam się przez płótna snów” $[\mathrm{O}, 44]$; „W szkarłacie, futrze, złotogłowiu / [...] brokatowych fałd, żakardowych haftów" [O: 46].

Obecność tych elementów kobiecego istnienia - nici, motków wełny, prześcieradeł, płócien, serwet, jedwabi, haftów - przywołuje na myśl rozważania Jolanty Brach-Czainy zawarte w książce Szczeliny istnienia. Objaśniając pojęcie krzątactwa jako fundamentu codzienności, filozofka pisała:

Podstawę naszego istnienia stanowi codzienność. [... zdarzenia codzienne są ostentacyjnie niezauważalne. Przepływają 
od istnienia do nieistnienia, w które zapadają, a swą krótką obecnością nie budzą uwagi. Codzienność jest bowiem rzeczywistością podwójnie umykającą. Przetacza się ku nieistnieniu i przejawia w niezauważalności. [... ] tylko w rzadkich chwilach koncentracji udaje nam się dostąpić jej objawienia w niezauważalności. [Brach-Czaina 1999: 55-61]

Latawiec w swojej poezji odnotowuje te "chwile koncentracji”, momentalne „objawienia codzienności w niezauważalności”. Co więcej, z doświadczania elementów powszednich czyni obrzęd poznania, kontemplacji, warunek pamięci, wreszcie także źródło twórczości. Doświadczenie zwykłego dnia objawia się fragmentarycznie, zaledwie cząstkowo, umykając uwadze, i tak właśnie zapisuje się w wierszach autorki Razem tu koncertujemy: w dostrzeżonych elementach, odblaskach, powidokach, można powiedzieć - w drobnych ściegach oraz zapętleniach życia.

Miller jako figurę kobiecego pisania przyjęła Arachne tkaczkę-pajęczycę (w języku greckim i francuskim słowo pająk jest rodzaju żeńskiego). Jednak liryka Latawiec to nie stateczna, umocowana sieć pajęczego tekstu, ale nić powiewająca, rozigrana, migotliwa, opalizująca wieloznacznościami. Świat przedstawiony jej utworów charakteryzuje nieustanne poruszenie. „Powracające w wierszach Latawiec - zauważyła Grądziel-Wójcik - motywy ruchu, drżenia, furkotu czy spadania polegają właśnie na rozprzestrzenianiu się bytu w niebycie” [Grądziel-Wójcik 2016a: 207]. Teresa Tomsia z kolei pisała: „Słowa wierszy wirują, uskrzydlone jak ptaki spłoszone w ogrodzie, raz w jasności, raz w mroku” [Tomsia 2012: 118]. Pozostając przy metaforyce tekstowej Miller, poezję Latawiec postrzegałabym w postaci nitek babiego lata ruchliwych, płynnych na wietrze, znikliwych w światłocieniach. Przywołam tylko kilka przykładów:

może z furkotem liści nadleci

chociaż strzęp minionego

biała nić śmiechu

lub skrawek oddechu;

[R: 58] 
Czasem przemknie po płótnie szyby oddychający liść;

[R:23]

a tak zwiewna

że nim do mnie doleciała

już z niej tylko puch

i biel bez ciężaru;

[G:37]

pierzaste cichostany

[...

bezszelestnie przelatują

[...] lądując

$\mathrm{w}$ cieple mojego snu;

[Z:23]

„furkocząc napiętym żaglem jasności” [Z: 45]; „o tę nić zieleni która wiruje w naszych oczach" [Z: 61].

Gdyby szukać patrona takiej poezji, mistrza, wielkiego prekursora, to byłby nim zapewne Adam Mickiewicz ${ }^{4}$ liryku lozańskiego Snuć miłość:

Snuć miłość, jak jedwabnik nić wnętrzem swym snuje,

Lać ją z serca, jak źródło wodę z wnętrza leje,

Rozwijać ją jak złotą blachę, gdy się kuje

Z ziarna złotego, puszczać ją w głąb, jak nurtuje

Źródło pod ziemią, - w górę wiać nią, jak wiatr wieje,

Po ziemi ją rozsypać, jak się zboże sieje.

[Mickiewicz 1948: 378]

4 Przywołanie poezji Mickiewicza w kontekście twórczości Latawiec ma, jak się wydaje, głębokie uzasadnienie. W autobiograficznym szkicu Mickiewicz udomowiony Latawiec zapisywała: „Mickiewicz był w naszym domu od zawsze. [...] Któregoś wieczoru - nie pamiętam, czy chodziłam jeszcze do klasy czwartej, czy już do piątej, wzięłam do siebie Pana Tadeusza. [...] Olśnienie. Tak, tylko takie wysokie, palące słowo przychodzi mi teraz na myśl, gdy próbuję wyrazić to, co wtedy poczułam. Aż musiałam zmrużyć oczy, krew uderzyła mi do głowy... To było jak dotknięcie ust, serca gorącą dłonią" [Latawiec 2016: 279-281]. 
Słowo, jak pouczali mistycy, rodzi się w głębokości wnętrza, w człowieku wewnętrznym, we wglądzie wewnętrznym, by następnie - ukazuje to Mickiewicz - wylać się na zewnątrz, rozwiać, rozsypać. Podobne metatekstowe treści wypełniają wiersze Latawiec. Wielokrotnie zaświadcza ona o wewnętrznym stanie tworzenia, nasłuchiwania, wypatrywania skierowanego dogłębnie. W wierszu zatytułowanym Tuż przed możemy przeczytać:

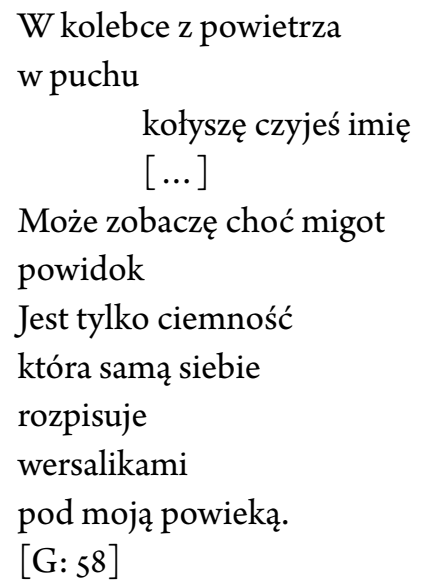

Tworzenie rozpoczyna się w głębokości „ja”, w ciemności, pod powieką. Obecność świata wewnętrznego, przeżyć, które się w nim rodzą, zaznacza podobnie Latawiec w tekście Drzewo - Ja:

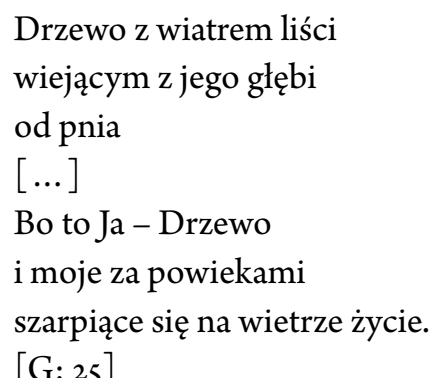

Wbrew jednak mistycznym przekonaniom Mickiewicza, jego wierze w „moc żywiołów”, „moc krzewienia” i przebóstwienia, Latawiec, jak kobieta, powie zaledwie: 
Gdy tylko dotknę językiem

tej umykającej mi od świtu istności

istnienia

$[\ldots]$

Po godzinie pracy

zostaną mi po niej

tylko furkoty

ucieczek.

[G: 13]

\section{Skróty}

$\mathrm{G}$ - Bogusława Latawiec, Gdyby czas byt ziemia

O - Bogusława Latawiec, Odkrytki

$\mathrm{R}$ - Bogusława Latawiec, Razem tu koncertujemy

Z - Bogusława Latawiec, Zmowy

\section{Bibliografia}

Brach-Czaina Jolanta (1999), Szczeliny istnienia, efKa, Kraków.

Fornalczyk Feliks (1965), Poezja niezbyt kobieca, „Głos Wielkopolski”, 10 października.

Głowiński Michał (1996), Jest wielkim poetą, w: Radość czytania Szymborskiej. Wybór tekstów krytycznych, oprac. Stanisław Balbus, Dorota Wojda, Społeczny Instytut Wydawniczy Znak, Kraków, s. 46-49.

Grądziel-Wójcik Joanna (2016a), Poznań w poezji Bogustawy Latawiec między „tym miastem” a „prywatna ciemnia”, w: tejże, Zmyst formy. Sytuacje, przypadki, interpretacje polskiej poezji XX wieku, TAiwPN Universitas, Kraków, s. 205-222.

Grądziel-Wójcik Joanna (2016b), „... zobaczone, dotknięte, pomyślane”. Bogusława Latawiec i Julian Przyboś, w: tejże, Przymiarki do istnienia. Wątki i tematy poezji kobiet Xx $i$ XxI wieku, Wydawnictwo Naukowe UAM, Poznań, s. 149-179.

Latawiec Bogusława (1999), Razem tu koncertujemy, Ars Nova, Poznań. Latawiec Bogusława (2007), Odkrytki, PIw, Warszawa.

Latawiec Bogusława (2011), Gdyby czas byt ziemia, Towarzystwo Przyjaciół Sopotu, Sopot. 
Latawiec Bogusława (2015), Zmowy, Wydawnictwo Forma, Fundacja Literatury imienia Henryka Berezy, Szczecin.

Latawiec Bogusława (2016), Mickiewicz udomowiony, w: Joanna

Grądziel-Wójcik, Piotr Łuszczykiewicz, Bogusława Latawiec. Portret podwojony, Wydawnictwo Pasaże, Kraków, s. 333-339.

Ligęza Wojciech (1983), Rytm środkowy, „Twórczość”, nr 1, s. 118-122. Łuszczykiewicz Piotr (2016), Wiersze, sny, obrazy Bogustawy Latawiec, w: Joanna Grądziel-Wójcik, Piotr Łuszczykiewicz, Bogusława Latawiec. Portret podwojony, Wydawnictwo Pasaże, Kraków, s. 13-47. Mazurek Anna (2008), Wstęga Möbiusa, „Akcent”, nr 3, s. 134-139.

Michałowski Piotr (1999), Zwierzęta nocy w ogrodach dnia, „Pogranicza”, nr 6, s. 81-83.

Mickiewicz Adam (1948), Snuć mitość, w: tegoż, Dzieła, t. 1, oprac.

Wacław Borowy, Leon Płoszewski, Spółdzielnia Wydawnicza

Czytelnik, Warszawa, s. 378.

Miller Nancy K. (2006), Arachnologie: kobieta, tekst i krytyka, przeł. Krystyna Kłosińska, Krzysztof Kłosiński, w: Teorie literatury xx wieku. Antologia, red. Anna Burzyńska, Michał Paweł Markowski, Społeczny Instytut Wydawniczy Znak, Kraków, s. 487-513.

Szaruga Leszek (2000), Między wierszami (I), „Kultura”, nr 4, s. 135-139. Szymańska Adriana (1999), Czas, którego nie ma, „Przegląd Powszechny”, nr 12, s. 366-369.

Tomsia Teresa (2012), Stacja metafizyczna na drodze poznania ( $w$ nowych wierszach Bogusławy Latawiec), „Topos”, nr 4, s. 115-119.

Węgrzyniakowa Anna (2002), Uczennice Przybosia, w: Stulecie Przybosia, red. Stanisław Balbus, Edward Balcerzan, Poznań, s. 177-190.

Woroszylski Wiktor (1995), Dwugłos o „nigdy całości”, „Arkusz”, nr 4, s. 9.

Joanna Dembińska-Pawelec

\section{Arachne with the etherial thread. Women's signature in the late} poetry of Bogusława Latawiec

The author of this sketch interprets Bogusława Latawiec's poems in the context of women's signatures. Poetry of Latawiec was usually read by critics in relation to the Polish avant-garde tradition represented by men: J. Przyboś and T. Karpowicz. The author recalls N. K. Miller's proposition of feminist reading and her theory of text as an arachnology. Analysing Latawiec's poems she shows some signs of feminine writing contained in metaphors: a thread, textiles, weaving, sewing, needlework. These signs are of particular importance in the metatextual poems talking about the process of creating as a weaving a text. 
Keywords: poetry; Bogusława Latawiec; arachnology; N.K. Miller.

Joanna Dembińska-Pawelec - dr hab. prof. uś, pracuje w Zakładzie Teorii Literatury na Wydziale Filologicznym Uniwersytetu Śląskiego. Prowadzi badania z zakresu poezji współczesnej, genologii oraz interferencji literatury i sztuki. Autorka książek: Światy możliwe w poezji Stanisława Barańczaka (1999), Villanella. Od Anonima do Barańczaka (2006), „Poezja jest sztuka rytmu”. O świadomości rytmu w poezji polskiej dwudziestego wieku (MiłoszRymkiewicz - Barańczak) (2010), Arabeska. Szkice o poezji (2013). Publikowała m.in. w „Pamiętniku Literackim”, „Poznańskich Studiach Polonistycznych”, „Śląskich Studiach Polonistycznych” i „Postscriptum Polonistycznym”. 
